\title{
Effect of Pot Volume on the Growth of Sweetpotato Cultivated in the New Hydroponic System
}

\author{
Masaru Sakamoto ${ }^{1} \&$ Takahiro Suzuki $^{1}$ \\ ${ }^{1}$ Faculty of Biology-Oriented Science and Technology, Kindai University, Wakayama 649-6493, Japan \\ Correspondence: Masaru Sakamoto, Faculty of Biology-Oriented Science and Technology, Kindai University, \\ Wakayama 649-6493, Japan. Tel: 81-0736-77-0345. E-mail: sakamoto@waka.kindai.ac.jp
}

Received: November 20, 2017

Accepted: December 8, 2017 Online Published: January 12, 2018

doi:10.5539/sar.v7n1p137

URL: http://dx.doi.org/10.5539/sar.v7n1p137

\begin{abstract}
Hydroponics is an effective means for promoting plant growth as it facilitates water and nutrient uptake by plant roots. For increasing the production of sweetpotato (Ipomoea batatas), we developed the new hydroponic cultivation system in which tuberous roots were grown in solid media in the pots whereas fibrous roots were grown in the nutrient solution. Using this method, the effect of pot volume $(1.6,3.0$, and $4.5 \mathrm{~L})$ on the growth of sweetpotato was investigated. When plants were grown in small-sized pots $(1.6 \mathrm{~L})$, the fresh weight of the top and that of tuberous roots were decreased compared with plants grown in $3.0 \mathrm{~L}$ and $4.5 \mathrm{~L}$ pots. No clear difference was observed between the top and the tuberous roots in terms of the dry weight ratio, regardless of the pot size. The number of tuberous roots per plant and the maximum tuberous root weight were not influenced by the pot size either. However, the number of tuberous roots weighing more than $100 \mathrm{~g}$ was decreased in plants grown in small pots. Some of the tuberous roots grown in this hydroponic system contained a non-hypertrophic parts with severely lignified metaxylems. These results suggest that the environment surrounding the tuberous root influenced by the pot volume may be important for root enlargement in this hydroponic system.
\end{abstract}

Keywords: sweetpotato, hydroponics, pot size, tuberous roots, pencil roots

\section{Introduction}

Sweetpotato (Ipomoea batatas) is cultivated in temperate and tropical climates and has the ability to fix a relatively large amount of solar energy even when grown in poor nutrient condition (Pimentel et al., 2002). In recent years, sweetpotato has become a potential resource for the production of cost-effective biofuels because of its ability to efficiently convert solar energy into sugar (Koçar \& Civaş, 2013). Root crops, such as sweetpotato and cassava have been proposed as substitutes for corn-based ethanol production considering their high ratio of output (bioethanol produced from such crops) to input (estimates of fertilizer, water, and pesticide) (Ziska et al., 2009). Several studies have been reported to have developed efficient biofuel extraction methods from sweetpotatoes and their residues in the form of hydrogen, ethanol, and methane (Chu et al., 2012; Lay et al., 2012; Kobayashi et al., 2014; Wang F. et al., 2016).

In temperate areas of Japan, edible and industrial sweetpotatoes are widely cultivated. In addition, demand for sweetpotato as a biofuel resource may be increased in the future for the production of substitute energy sources, such as nuclear power. However, the number of workers in the agriculture sector is steadily declining in Japan because of their increasing age. Therefore, it is necessary to develop the cost-effective methods for efficient cultivation of sweetpotato.

Hydroponics is a cultivation method that uses mineral nutrient solutions in a water solvent, instead of solid medium (soil) and fertilizer. In this method, plant roots are either directly exposed to the mineral nutrient solution or indirectly supported by highly absorbent material, such as vermiculite, perlite, and rock wool that easily absorb the nutrient solution. Hydroponic cultivation systems often provide rapid growth of plants by efficiently feeding nutrients to the roots, as the rhizospheres are constantly surrounded by nutrient-dense water essential for plant growth. Although the practical use of hydroponics is restricted mainly to leafy vegetables and some fruit crops, studies have been conducted to establish the use of hydroponic systems for root vegetables. Previous studies have demonstrated that the degree of immersion of carrots (Daucus carota) roots in nutrient solutions affects the tap root development regardless of the hydroponic systems used (Terabayashi et al., 2008; Kusakawa \& Inoue, 2010; Eguchi et al., 2011). Experiments have also been conducted to investigate the 
tuberous root characteristics of sweetpotato when grown in a hydroponic systems (Eguchi et al., 1996; Kitaya et al., 2008). The hydroponic method that cultivates tuberous roots in air and fibrous roots in nutrient solution revealed that humidity is an important factor for the development of tuberous roots (Eguchi et al., 1998). Although this study enabled the sequential observations of tuberous root growth, its practical application might be obscure as it only used plants in which the tuberous roots had already differentiated, and these plants were cultivated only for 4 days in the hydroponic system (Eguchi et al., 1998). Sweetpotato has also been cultivated from stem cuttings using rock wool slab-based hydroponic method (Kitaya et al., 2008). However, this system was complex and expensive that designed to utilize for space farming. These results recommended the development of new cost-effective hydroponic systems. Here, we constructed a cost-effective hydroponics system for sweetpotato cultivation. Using this hydroponic system, we investigated the effect of pot volume on the growth of sweetpotato.

\section{Method}

\subsection{Plant Materials and Cultivation Methods}

Sweetpotato (Ipomoea batatas) cultivar "Narutokintoki" was used in our study. The experimental hydroponics system was constructed based on passive hydroponics (Figure 1). Black vinyl pots filled with vermiculite were placed on corrugated plastic boards. To bring the vermiculite in direct contact with the water absorption sheet placed on the plastic boards, holes were made in the bottom of the pots. The ends of the water absorption sheet were soaked in nutrient solution, which enabled the transport of nutrients to the vermiculite by capillary action. Vermiculite was kept saturated with nutrient solution throughout the cultivation period. Culture containers $(59 \times$ $39 \times 18 \mathrm{~cm}$ ) were set under the plastic boards and filled with nutrient solution with a half-strength culture solution of OAT House recipe A (Sakamoto \& Suzuki, 2015a, 2015b; Sakamoto et al., 2016). Reduction in the level of nutrient solution due to plant uptake or water evaporation was compensated for by the addition of water. Nutrient solution was exchanged every 2 weeks. Pot surface was sealed with silver insulation sheets to avoid excess water evaporation and pest contamination. Plastic boards and culture containers were also covered with these insulation sheets to enable maximum utility of sunlight for photosynthesis by reflection. Two separate experiments were conducted over two years (2015 and 2016) using different sized pots. Experiment 1 used 3.0 L pots $(14.0 \mathrm{~cm}$ lower diameter $\times 15.5 \mathrm{~cm}$ height $)$, whereas experiment 2 used three different sized pots: $1.6 \mathrm{~L}$ $(10.3 \mathrm{~cm} \times 12.5 \mathrm{~cm}), 3.0 \mathrm{~L}(14.0 \mathrm{~cm} \times 15.5 \mathrm{~cm})$, and $4.5 \mathrm{~L}(15.0 \mathrm{~cm} \times 21.0 \mathrm{~cm})$.

In experiment 1 , stem cuttings of sweetpotato were planted in vermiculite-filled vinyl pots and grown for 14 days. Pots were then transferred to the hydroponic system (1 pot per cultivation container) and cultured for 76 days from June 16 to August 31 in 2015 on the experimental field of Kindai University (Faculty of Biology-Oriented Science Technology, Wakayama, Japan). In experiment 2, the stem cuttings planted in vermiculite-filled vinyl pots and were grown for 10 days using the same growth conditions as those used for experiment 1 . Pots were then transferred to the hydroponic system (4 pots per cultivation container) and cultured for 159 days from May 7 to October 13 in 2016 in the experimental field of Kindai University.

The top, tuberous roots, and fibrous roots of each plant were dried in an oven for more than 7 days at $80^{\circ} \mathrm{C}$, and the dry weight were measured. In experiment 2, the average dry weight of 8 plants was calculated, except for those of fibrous roots. Because fibrous roots were intertwined with the absorption sheet and the cultivation container, total weight of the roots was measured and weight per plant was calculated.

\subsection{Lignin Staining}

Microscopic analysis of lignin was conducted as previously described (Zhong et al., 2000). Enlarged tuberous roots and pencil-type roots were sectioned free hand using a razor blade or a cutter knife. Sections were stained with $1 \%$ phloroglucinol- $\mathrm{HCl}$ solution for $5 \mathrm{~min}$ and observed under stereo- and light microscope.

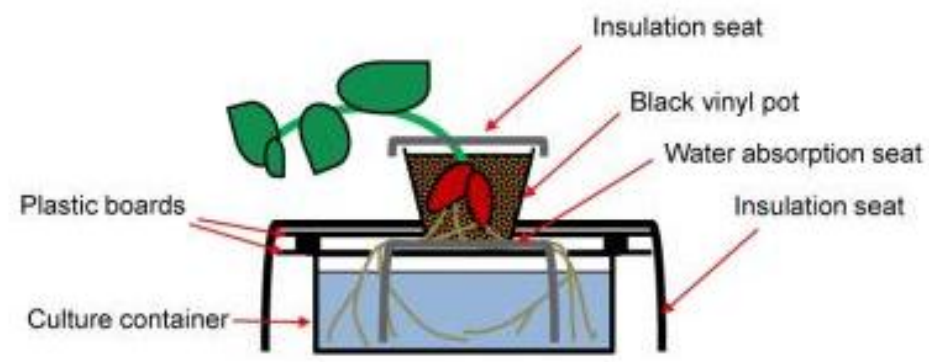

Figure 1. Hydroponic system used for the cultivation of sweetpotato in experiments 1 and 2 


\section{Results and Discussion}

We developed the new hydroponic system for the cultivation of sweetpotato (Figure 1). The first experiment (experiment 1 ) was conducted for preliminary examination to check whether this hydroponic system ensures the formation of tuberous roots of sweetpotato. After 90 days from the plantation of sweetpotato cuttings in this system, fibrous roots extended through the water absorption sheet into the cultivation container (Figure 2A). Enlarged tuberous roots of sweetpotato developed in the pots filled with vermiculite; tuberous roots were never observed in the water absorption sheets or the cultivation container. These data coincides with the previous report wherein complete immersion of the root system in the nutrient solution restricted the formation of tuberous roots in sweetpotato (Eguchi \& Yoshida, 2004). Tuberous roots were formed in all four plants cultivated in this system (Figure 2B). Fresh weights of top and tuberous roots per plant were $143.0 \pm 18.0 \mathrm{~g}$ (mean \pm SE) and $294.5 \pm 46.1 \mathrm{~g}$, respectively, whereas the corresponding dry weights were $23.7 \pm 3.7 \mathrm{~g}$ and $74.8 \pm 0.9 \mathrm{~g}$, respectively. The average number of tuberous roots per plant was $3.75 \pm 0.48$. Although the duration of the hydroponic cultivation in this experiment (90 days post plantation of sweetpotato cuttings) was shorter than that of field cultivation in Japan (120-160 days post plantation), several thickened tuberous roots were obtained in all plants. To harvest larger tuberous roots, we extended the cultivation period to 159 days in the second experiment.
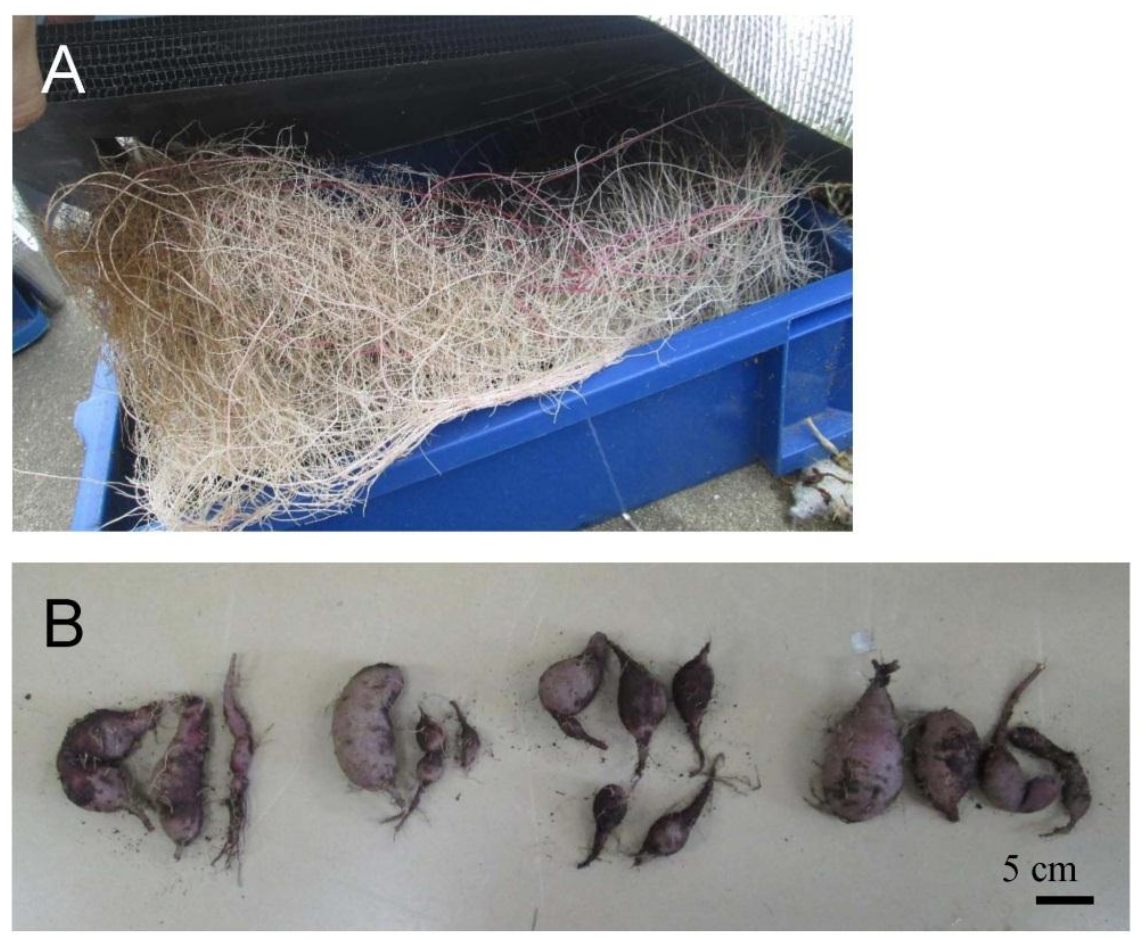

Figure 2. Sweetpotato fibrous and tuberous roots 90 days after plantation in experiment 1. (A) Fibrous roots extended in the cultivation container. (B) Tuberous roots harvested from four plants

In experiment 2, we examined the effect of pot size $(1.6,3.0$, and $4.5 \mathrm{~L})$ on the growth of sweetpotato in order to determine the minimum amount of vermiculite required for tuberous root enlargement. After 159 days, all plants in each pot formed some tuberous roots (Figure 3). The average biomass of tuberous roots was lower in plants grown in $1.6 \mathrm{~L}$ pots compared with plants grown in $3.0 \mathrm{~L}$ and $4.5 \mathrm{~L}$ pots (Figures $4 \mathrm{~A}$ and $5 \mathrm{~A}$ ). Average fresh weights of plants grown in $1.6 \mathrm{~L}, 3.0 \mathrm{~L}$, and $4.5 \mathrm{~L}$ pots were $668.2 \mathrm{~g}, 923.9 \mathrm{~g}$, and $892.2 \mathrm{~g}$, respectively. Top fresh weight was also reduced in plants grown in $1.6 \mathrm{~L}$ pot (Figure 4B). In contrast, the fresh weight of fibrous roots was decreased with an increase in pot size (Figure 4C). Total plant biomass, represented by the sum of dry weights of top, tuberous roots, and fibrous roots, was lower in plants grown in $1.6 \mathrm{~L}$ pots than in those grown in 3.0 and $4.5 \mathrm{~L}$ pots (Figure 5A). The ratio between the dry weights of the top and the tuberous roots did not differ between plants grown in pots of different size (Figure 5B). These data suggest that pots with a volume of $3.0 \mathrm{~L}$ or higher are necessary to obtain sufficient tuberous root yield using this hydroponic system under similar experimental conditions. In a previous report, the tuberous roots of sweetpotato became smaller when young seedlings were cultivated in a small plastic case. (Adachi et al., 2016). This suggests that tuberous roots of plants 
grown in small pots in our study may undergo greater physical pressure than those of plants grown in larger pots, thus resulting in limited enlargement of tuberous roots in small pots.

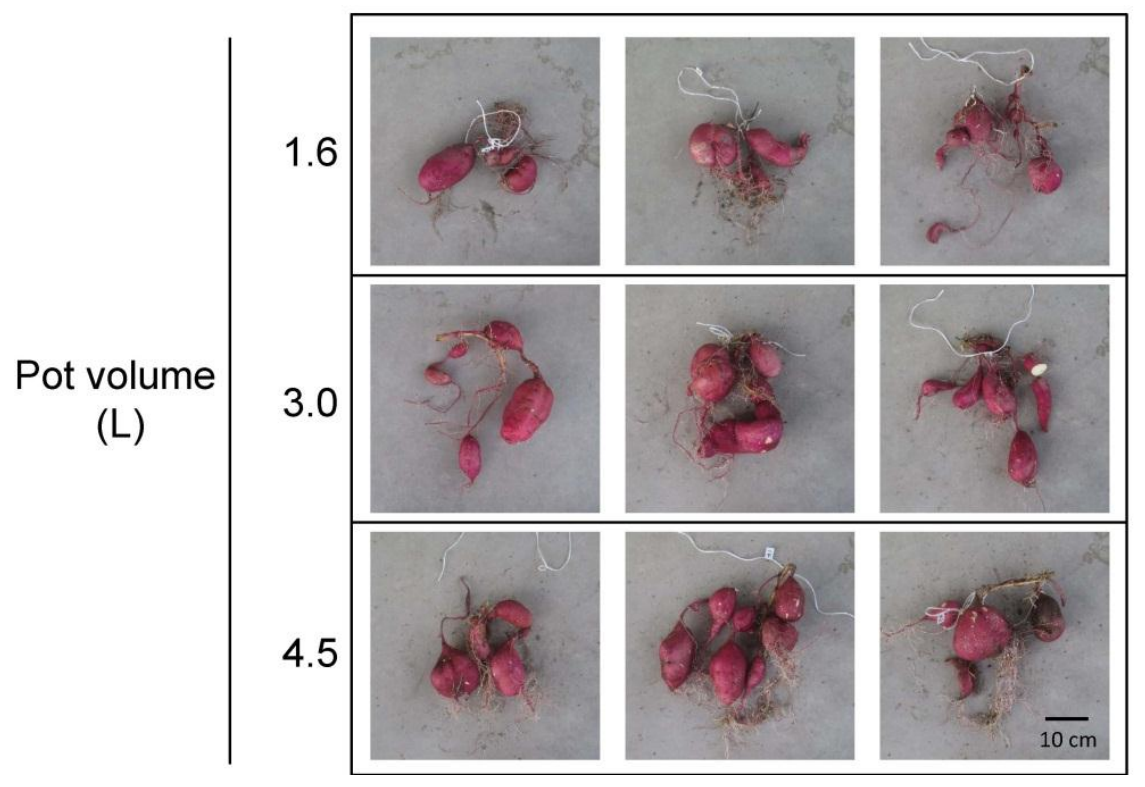

Figure 3. The effect of pot volume on tuberous root growth of sweetpotato plants 159 days after plantation in experiment 2
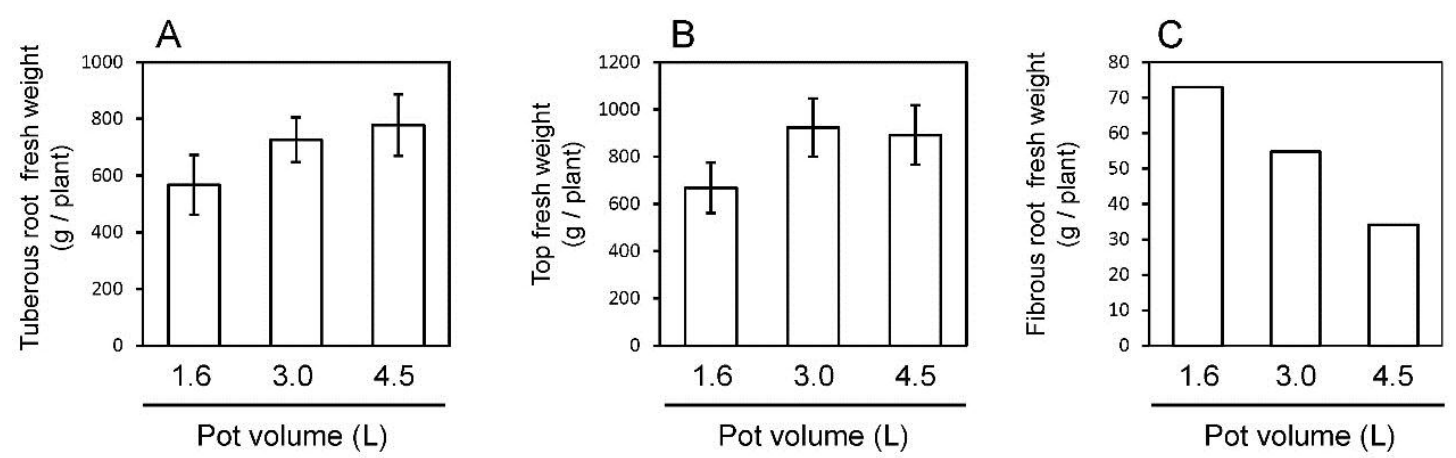

Figure 4. The effect of pot volume on the fresh weight of tuberous roots (A), top (B), and fibrous roots (C) of sweetpotato plants 159 days after plantation in experiment 2. Vertical bars represent mean $\pm \operatorname{SE}(n=8)$
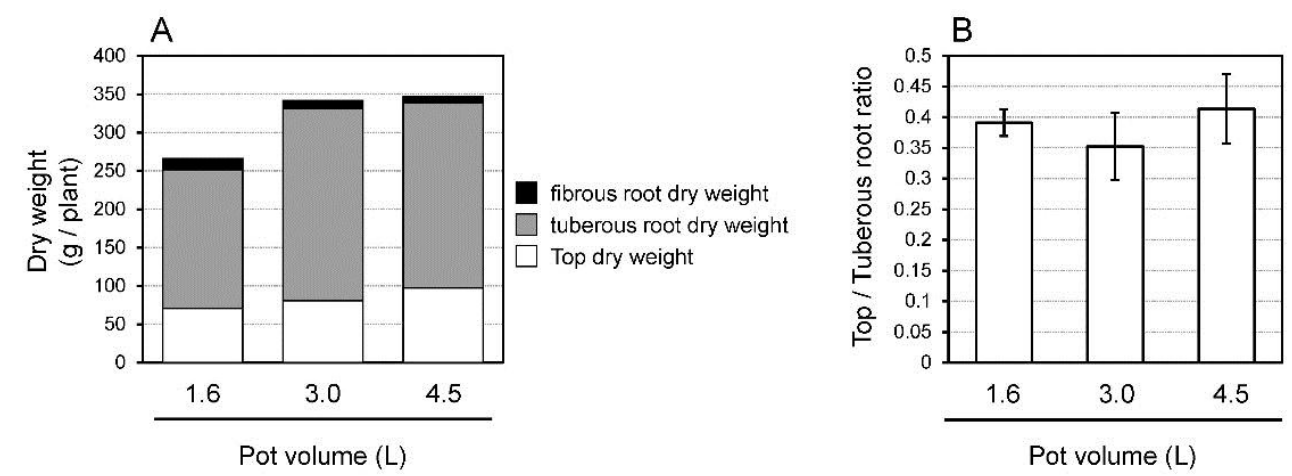

Figure 5. The effect of pot volume on dry weight (A) and top/tuberous root ratio (B) of sweetpotato plants 159 days after plantation in experiment 2 . Vertical bars represent mean $\pm \operatorname{SE}(n=8)$ 
Although the number of tuberous roots per plant and the maximum tuberous root weight were not affected by the pot volume, the number of tuberous roots weighing over $100 \mathrm{~g}$ were lower in $1.6 \mathrm{~L}$ pots than in larger pots (Figure 6). These data imply that some tuberous roots may have suppressed the enlargement of other tuberous roots in $1.6 \mathrm{~L}$ pots. Tuberous root enlargement depends on the environment including the soil (Eguchi et al., 1998, 2003). Using a laser micrometer system, the tuber volume was observed to increase during the night, and the tuber volume was influenced by ambient humidity (Eguchi et al., 1998). In our study, deformities in vinyl pots were observed as the tuberous root volume increased at later stages of growth, even in 3.0 L pots (Figure 7B). Given that root zone temperature at day and night also influences tuberous root enlargement (Eguchi et al., 2003), extreme deformities in $1.6 \mathrm{~L}$ pots might have modified the soil environmental condition including temperature and humidity surrounding the tuberous roots, resulting in limited enlargement of tuberous roots.
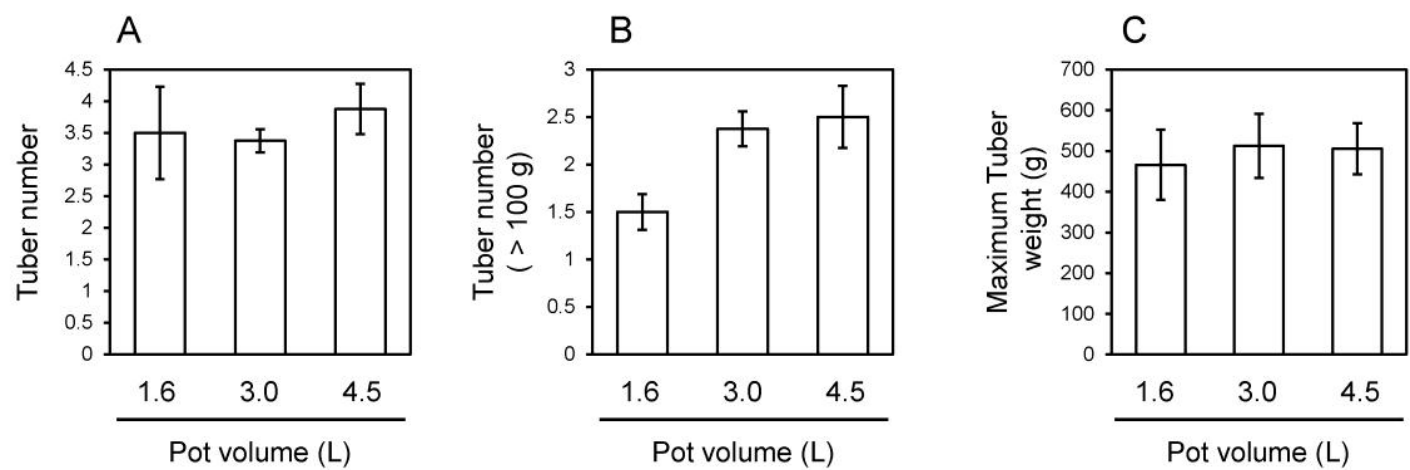

Figure 6. The effect of pot volume on the total number of tuberous roots (A), number of tuberous roots over $100 \mathrm{~g}$ (B), and maximum tuberous root weight (C) of sweetpotato plants 159 days after plantation in experiment 2.

Vertical bars represent mean $\pm \mathrm{SE}(n=8)$.
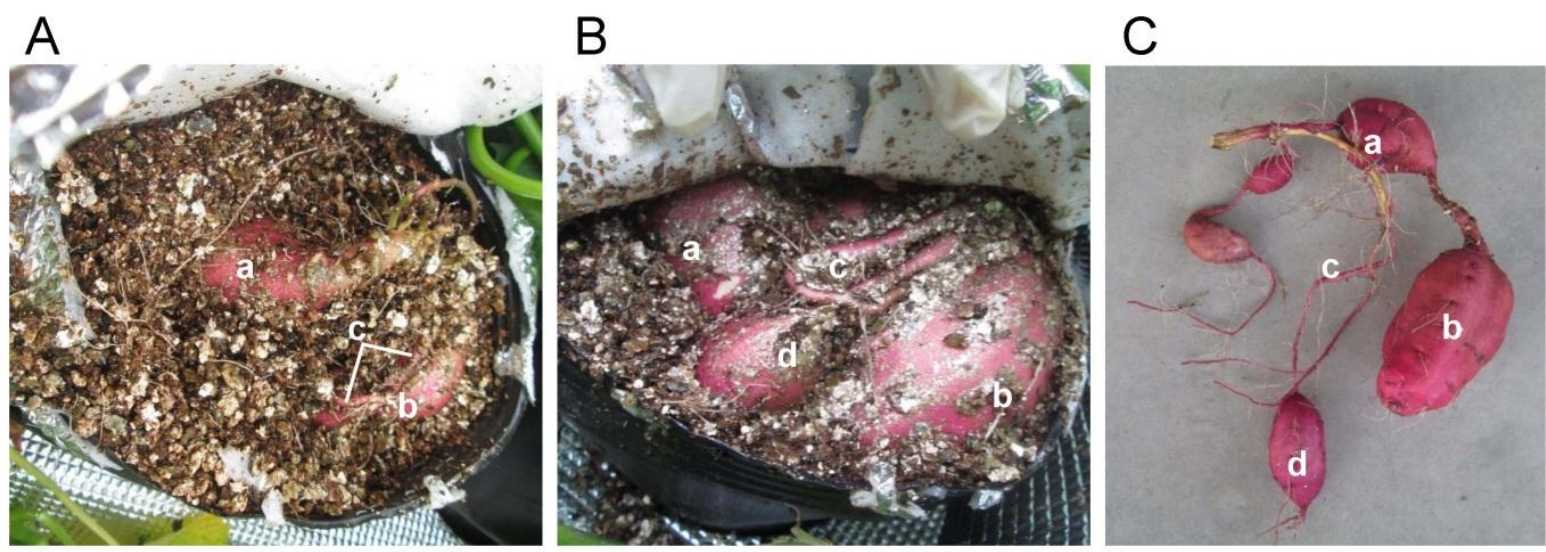

Figure 7. Temporal changes in tuberous roots of sweetpotato plants grown in 3.0 L pots in experiment 2. Tuberous roots of the same plant at 79 (A), 149 (B), and 159 days (C) after plantation are shown. Same alphabet in pictures represents identical part of tuberous roots at different growth stages. 

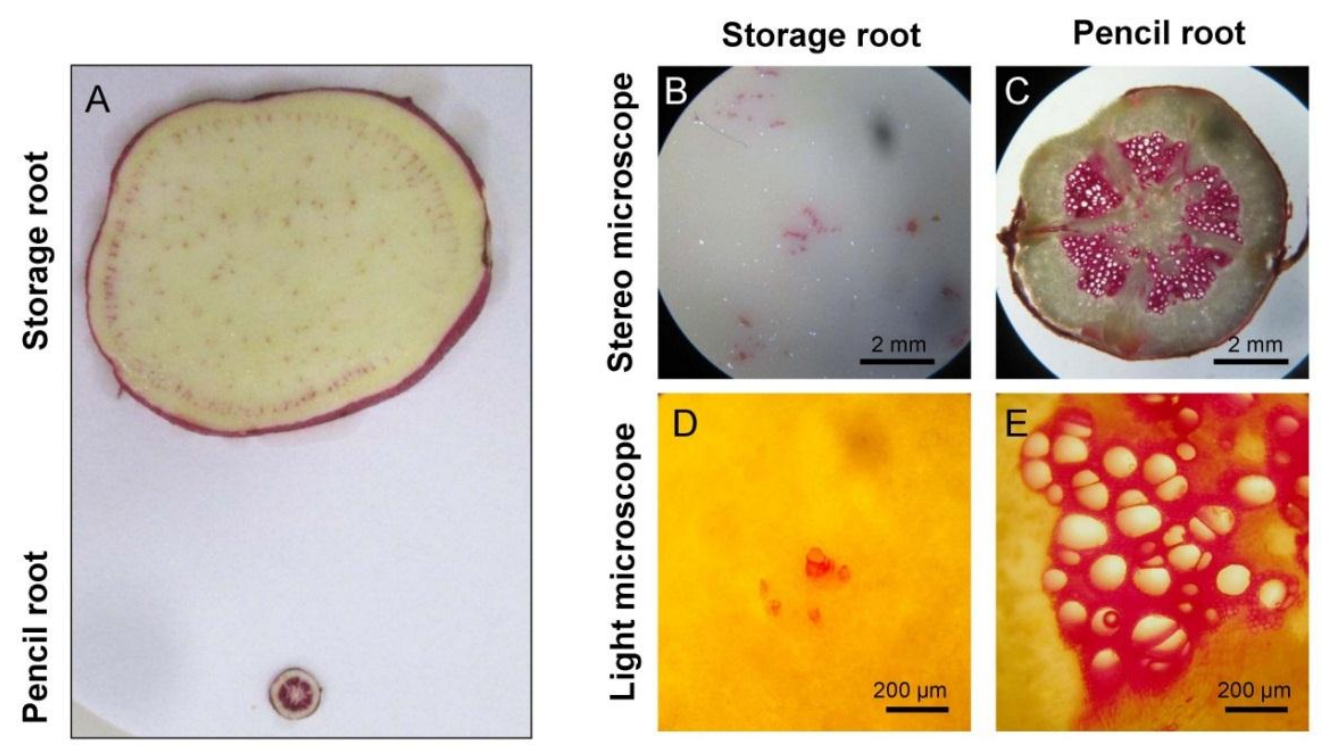

Figure 8. Lignin content in storage and pencil-type roots shown in Figure 7C. Cross-sections of storage and pencil-type roots stained with $1 \%$ phloroglucinol- $\mathrm{HCl}$ solution $(\mathrm{A})$ observed under stereomicroscope $(\mathrm{B}, \mathrm{C})$ and light microscope $(\mathrm{D}, \mathrm{E})$.

The growth characteristics of tuberous roots were monitored during hydroponic cultivation by opening the silver insulation sheets covering vermiculite (Figure 7). Enlarged tuberous roots were observed at 79 days post plantation and their sizes were noted to have increased at 146 days post plantation (Figures 7A and 7B). Some parts of tuberous roots showed restricted enlargement known as pencil-type roots (Figure 7C). Pencil-type roots were differentiated at early period (within 26 days from transplanting) of sweetpotato cultivation, accompanied by the expansion of lignified root structures (Villordon et al., 2009). Consistent with this observation, the pencil-type root parts identifiable at 79 days post plantation (Figure 7A) and their volumes had barely increased when observed at 146 days and 159 days post plantation (Figures 7B and 7C). Lignin staining revealed the existence of lignified structures in tuberous roots of enlarged and pencil-type root parts from plants harvested at 159 days (Figure 8A). In enlarged roots, a small collection of lignified cells was observed scattered, which presumably functioned as xylems (Figures 8B and 8D). Pencil-type roots contained large lignified structures known as metaxylems (Figures 8C and 8E). Differentiation of tuberous roots from adventitious roots coincides with an increase in the activity of primary cambium and a decrease in the lignification of stele (Togari, 1950). Consistent with this observation, genes involved in lignin biosynthesis are down-regulated during the initiation of tuberous root development (Firon et al., 2013; Wang et al., 2015). In addition, overexpression of Maize Lc gene in transgenic sweetpotato induced the activation of the lignin biosynthetic pathway in the developing roots, leading to pencil-type root differentiation (Wang H. et al., 2016). Given that pencil-type root parts were observed in our study, it is possible that restriction of initial adventitious root elongation due to the small pot size triggered several stresses at the stage of tuberous root development, resulting in the emergence of pencil-type root parts. The vinyl pots may have caused partial contact of the initial roots to the bottom and sides of the pot, which could have made low humidity conditions unsuitable for tuberous root development. As drought stress induces stress-responsive genes and restricts tuberous root development (Ogawa et al., 2006; Gajanayake et al., 2013; Solis et al., 2014), the initial roots contacted with vinyl pots may undergo drought-like stress. Genes encoding antioxidant enzymes, which are often activated during drought stress, are upregulated in pencil-type roots compared with tuberous roots (Kim et al., 2015). As observed in previous hydroponic studies on sweetpotato (Kitaya et al., 2008), transplanting sweetpotato seedlings containing already developed tuberous roots might restrict the formation of pencil-type roots.

In root and tuber crops, hormone-signaling networks control root architecture (Villordon et al., 2014). In sweetpotato, endogenous levels of cytokinin and auxin rapidly increase in the roots during tuberous root development (Nakatani \& Komeichi, 1991). Exogenous application of cytokinin also activates tuberous root formation (McDavid \& Alamu, 1980; Eguchi \& Yoshida, 2008). Given that SRD1, a gene which activates the 
development of storage roots, is highly induced by exogenous auxin treatment (Noh et al., 2010), manipulations of root hormonal levels using pharmacological treatments or environmental regulation may be employed to increase the tuberous root yield. Our hydroponic system may be effective to control root hormonal levels as the tuberous roots were grown in the small pots.

\section{Conclusions}

Although several studies have demonstrated hydroponic cultivation of sweetpotato with or without absorbent materials (Eguchi et al., 1996; Kitaya et al., 2008), these studies used young sweetpotato plants, which had already acquired the ability to develop tuberous roots. In contrast, in our study, stem cuttings were directly transplanted to the pots, thus saving the cost of labor required to prepare plants with differentiated tuberous roots from stems. In addition, our system saves absorbent materials (soil) and can be used at any place that is exposed to sunlight. Therefore, our hydroponic system may be capable of lowering the cost of labor and resources needed for mass production of sweetpotato.

\section{References}

Adachi, K., Omine, M., Sugimoto, M., Ishii, T., Niimi, H., Suzuki, T., Kamebayashi, M., Takada, M., Gotoh, A., and Yokoyama, K. (2016). Yield-enhancing and tuber-downsizing effects of transplantation cultivation method of case-held tuber seedlings in the sweet potato cultivar Beniharuka. Plant Production Science, 19, 125-131. https://doi.org/10.1080/1343943X.2015.1128086

Chu, C. Y., Sen, B., Lay, C. H., Lin, Y. C., \& Lin, C. Y. (2012). Direct fermentation of sweet potato to produce maximal hydrogen and ethanol. Applied Energy, 100, 10-18. https://doi.org/10.1016/j.apenergy.2012.06.023

Eguchi, T., Kitano, M., \& Eguchi, H. (1996). New system of hydroponics for growth analysis of sweet potato tuber. Biotronics, 25, 85-88.

Eguchi, T., Kitano, M., \& Eguchi, H. (1998). Growth of sweetpotato tuber as affected by the ambient humidity. Biotronics: Reports of Biotron Institute, Kyushu University, 27, 93-96.

Eguchi, T., Kitano, M., Yoshida, S., \& Chikushi, J. (2003). Root temperature effects on tuberous root growth of sweetpotato (Ipomoea batatas Lam.). Environment Control in Biology, 41(1), 43-49. https://doi.org/10.2525/ecb1963.41.43

Eguchi, T., \& Yoshida, S. (2004). A cultivation method to ensure tuberous root formation in sweetpotatoes (Ipomoea batatas (L.) Lam.). Environment Control in Biology, 42(4), 259-66. https://doi.org/10.2525/ecb1963.42.259

Eguchi, T., \& Yoshida, S. (2008). Effects of application of sucrose and cytokinin to roots on the formation of tuberous roots in sweetpotato (Ipomoea batatas (L.) Lam.). Plant Root, 2, 7-13. https://doi.org/10.3117/plantroot.2.7

Eguchi, T., Suzuki, T., Yoshida, S., Miyajima, I., \& Kitano, M. (2011). Time-course pattern of carrot storage root growth in a solid substrate, sub-irrigation culture system. Environmental Control in Biology, 49(4), 177-183. https://doi.org/10.2525/ecb.49.177

Firon, N., LaBonte, D., Villordon, A., Kfir, Y., Solis, J., Lapis, E., Perlman, T. S., Doron-Faigenboim, A., Hetzroni, A., Althan, L., \& Nadir, L. A. (2013). Transcriptional profiling of sweetpotato (Ipomoea batatas) roots indicates down-regulation of lignin biosynthesis and up-regulation of starch biosynthesis at an early stage of storage root formation. BMC Genomics, 14(1), 460. https://doi.org/10.1186/1471-2164-14-460

Gajanayake, B., Reddy, K. R., Shankle, M. W., \& Arancibia, R. A. (2013). Early-season soil moisture deficit reduces sweetpotato storage root initiation and development. HortScience, 48(12), 1457-1462.

Kim, Y. H., Park, S. C., Ji, C. Y., Lee, J. J., Jeong, J. C., Lee, H. S., \& Kwak, S. S. (2015). Diverse antioxidant enzyme levels in different sweetpotato root types during storage root formation. Plant Growth Regulation, 75(1), 155-164. https://doi.org/10.1007/s10725-014-9940-x

Kitaya, Y., Hirai, H., Wei, X., Islam, A. F. M. S., \& Yamamoto, M. (2008). Growth of sweetpotato cultured in the newly designed hydroponic system for space farming. Advances in Space Research, 41(5), 730-735. https://doi.org/10.1016/j.asr.2007.09.005

Kobayashi, T., Tang, Y., Urakami, T., Morimura, S., \& Kida, K. (2014). Digestion performance and microbial community in full-scale methane fermentation of stillage from sweet potato-shochu production. Journal of Environmental Sciences, 26(2), 423-431. https://doi.org/10.1016/S1001-0742(13)60423-4

Koçar, G., \& Civaş, N. (2013). An overview of biofuels from energy crops: Current status and future prospects. 
Renewable and Sustainable Energy Reviews, 28, 900-916. https://doi.org/10.1016/j.rser.2013.08.022

Kusakawa, T., \& Inoue, M. (2010). Damage to pot-cultured carrot growth due to a temporarily raised groundwater level and flooding period. Horticultural Research (Japan), 9(4), 495-500. https://doi.org/10.2503/hrj. 9.495

Lay, C. H., Lin, H. C., Sen, B., Chu, C. Y., \& Lin, C. Y. (2012). Simultaneous hydrogen and ethanol production from sweet potato via dark fermentation. Journal of Cleaner Production, 27, 155-164. https://doi.org/10.1016/j.jclepro.2011.12.027

McDavid, C. R., \& Alamu, S. (1980). The effect of growth regulators on tuber initiation and growth in rooted leaves of two sweet potato cultivars. Annals of Botany, 45(3), 363-364. https://doi.org/10.1093/oxfordjournals.aob.a085833

Nakatani, M., \& Komeichi, M. (1991). Changes in the endogenous level of zeatin riboside, abscisic acid and indole acetic acid during formation and thickening of tuberous roots in sweet potato. Japanese Journal of Crop Science, 60(1), 91-100. https://doi.org/10.1626/jcs.60.91

Noh, S. A., Lee, H. S., Huh, E. J., Huh, G. H., Paek, K. H., Shin, J. S., \& Bae, J. M. (2010). SRD1 is involved in the auxin-mediated initial thickening growth of storage root by enhancing proliferation of metaxylem and cambium cells in sweetpotato (Ipomoea batatas). Journal of Experimental Botany, 61(5), 1337-1349. https://doi.org/10.1093/jxb/erp399

Ogawa, H., Kakehashi, Y., Inoue, M., Tanabe, K., \& Otani, H. (2006). Influence that transition of soil moisture exerts on amount and quality of sweet potato in a sandy field. Tokushima Noken Hou (Japan), 3, 13-19.

Pimentel, D., Doughty, R., Carothers, C., Lamberson, S., Bora, N., \& Lee, K. (2002). Energy inputs in crop production in developing and developed countries. Food Security and Environmental Quality in the Developing World, 129-151. https://doi.org/10.1201/9781420032215.ch8

Sakamoto, M., \& Suzuki, T. (2015a). Elevated root-zone temperature modulates growth and quality of hydroponically grown carrots. Agricultural Sciences, 6(8), 749-757. https://doi.org/10.4236/as.2015.68072

Sakamoto, M., \& Suzuki, T. (2015b). Effect of root-zone temperature on growth and quality of hydroponically grown red leaf lettuce (Lactuca sativa L. cv. Red Wave). American Journal of Plant Sciences, 6(14), 2350-2360. https://doi.org/10.4236/ajps.2015.614238

Sakamoto, M., \& Suzuki, T. (2016). Effect of root-zone temperature on the growth and fruit quality of hydroponically grown strawberry plants. Journal of Agricultural Science, 8(5), 122-131. https://doi.org/10.5539/jas.v8n5p122

Solis, J., Villordon, A., Baisakh, N., LaBonte, D., \& Firon, N. (2014). Effect of drought on storage root development and gene expression profile of sweetpotato under greenhouse and field conditions. Journal of the American Society for Horticultural Science, 139(3), 317-324.

Terabayashi, S., Harada, N., \& Fujime, Y. (2008). Effects of aeration and root immersion level on the development of carrot [Daucus carota] root in hydroponics. Horticultural Research (Japan), 7(3), 439-444. https://doi.org/10.2503/hrj.7.439

Togari, Y. (1950). A study on the tuberous-root formation of sweet-potatoes. Nourinshou Noujishikenjou Houkoku (Bull. Natl. Agric. Expt. Stn. (Tokyo)), 68, 1-96.

Villordon A. Q., La Bonte, D. R., Firon, N., Kfir, Y., Pressman, E., \& Schwartz, A. (2009). Characterization of adventitious root development in sweetpotato. HortScinece, 44, 651-655.

Villordon, A. Q., Ginzberg, I., \& Firon, N. (2014). Root architecture and root and tuber crop productivity. Trends in Plant Science, 19(7), 419-425. https://doi.org/10.1016/j.tplants.2014.02.002

Wang, Z., Fang, B., Chen, X., Liao, M., Chen, J., Zhang, X., Huang, L., Luo, Z., Yao, Z., \& Li, Y. (2015). Temporal patterns of gene expression associated with tuberous root formation and development in sweetpotato (Ipomoea batatas). BMC Plant Biology, 15(1), 180. https://doi.org/10.1186/s12870-015-0567-5

Wang, F., Jiang, Y., Guo, W., Niu, K., Zhang, R., Hou, S., Wang, M., Yi, Y., Zhu, C., Jia, C., \& Fang, X. (2016). An environmentally friendly and productive process for bioethanol production from potato waste. Biotechnology for Biofuels, 9, 50. https://doi.org/10.1186/s13068-016-0464-7

Wang, H., Yang, J., Zhang, M., Fan, W., Firon, N., Pattanaik, S., Yuan, L., \& Zhang, P. (2016). Altered phenylpropanoid metabolism in the maize $L c$-expressed sweet potato (Ipomoea batatas) affects storage root 
development. Scientific Reports, 6, 18645. https://doi.org/10.1038/srep18645

Zhong, R., Ripperger, A., \& Ye, Z. H. (2000). Ectopic deposition of lignin in the pith of stems of two Arabidopsis mutants. Plant Physiology, 123(1), 59-70. https://doi.org/10.1104/pp.123.1.59

Ziska, L. H., Runion, G. B., Tomecek, M., Prior, S. A., Torbet, H. A., \& Sicher, R. (2009). An evaluation of cassava, sweet potato and field corn as potential carbohydrate sources for bioethanol production in Alabama and Maryland. Biomass and Bioenergy, 33(11), 1503-1508. https://doi.org/10.1016/j.biombioe.2009.07.014

\section{Copyrights}

Copyright for this article is retained by the author(s), with first publication rights granted to the journal.

This is an open-access article distributed under the terms and conditions of the Creative Commons Attribution license (http://creativecommons.org/licenses/by/3.0/). 